\title{
テレビジョン信号計測の自動化
}

正会員 町 永 欣 一

テレビ信号を自動測定しようという試みが近年盛んである。Tektronix が開発したディジタル方 式自動測定システム“ANSWER”について原理と測定方法を簡単に述べ, 同時にディジタル信号 発生器 1900 型の特徴之新しい波形について考察する. また，乙の自動測定装置の利用例について 考えてみる.

1. ま え がき

テレビ信号を自動測定しようという試 みの歴史はかなり昔にさかのばる，特に ヨーロッパでは，ITSを使用しての自動 計測から自動補正を試みたものもかなり あった.テクトロニクスでは 9 年前の 1972 年, モントルー・テレビジョン・シ ンポジウムで垂直ブランキングテスト信 号の自動測定システムを発表した.

このシステムでは非直線ひずみの測定 とランダムノイズの軽減に多くのアナロ グ回路を使い，また $2 T$ パルス， $2 T$ バ 一信号等のピークや立上りを出すために フレームレートサンプルのH. SYNC か らの移相を制御し，等価サンプリング間 隔をせまくする手段をとっていたので, ノイズや信号自身の時間軸エラーによる サンプルエラーが測定エラーに直接関連 し，満足のできる結果は得られなかっ た.

テクトロニクスではてれらの経験から，高品質の自動 測定システムを作り上げるために，リアルタイムで処理 できる高精度高速 $\mathrm{A} / \mathrm{D}$ コンバーターを完成し，16ビ ットマイクロコンピューターとの結合により現在の ANSWER システムを作り上げている.

また，乙の自動測定システムを完成するに当り，正確 な NTC 7 VITS 信号が必要となった。 これは，通常の テレビ信号のひずみ測定では，比較測定でなく，オープ ンループの絶対測定を行うからである. それに加え，今

†ソニー・テクトロニクス株式会社

"Automated Measurement of TV Baseband Transmission Parameters" by Kinichi Machinaga (Sony Tektronix Corp., Tokyo)
ペリフェラルデバイス

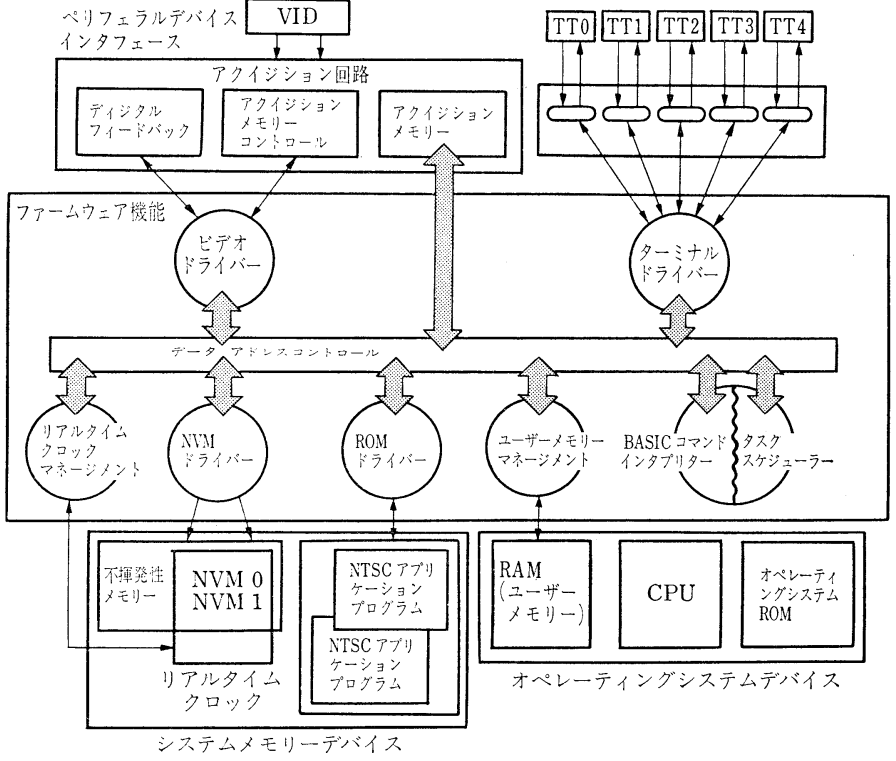

図 1 “ANSWER” のシステム構成図（ユーザーRAM は32k ワード, 波形メモリーは高速 ECL $32 \mathrm{k}$ バイト，アプリケーションプログラム は PROM 40k ワードある)
後の自動計測には信号発生器のコンピューターによる自 動制御も欠かせない機能となった。 これらを加味し，テ クトロニクスでは 10 ビット $4 f_{s c}$ のディジタルテレビ 信号発生器 1900 型を開発している. 今回は, このテレ ビジョン自動測定システム 1980 型“ANSWER”を主 に, 1900 型ディジタルゼネレーターにおける新しい試み についてす加えて述べてみたい.

\section{2. システムの構成}

\section{1 全体構成}

図 1 にシステム構成図を示す。基本概念は高速 $\mathrm{A} / \mathrm{D}$ コンバーターを含もデータアクイジション部と, TMS 

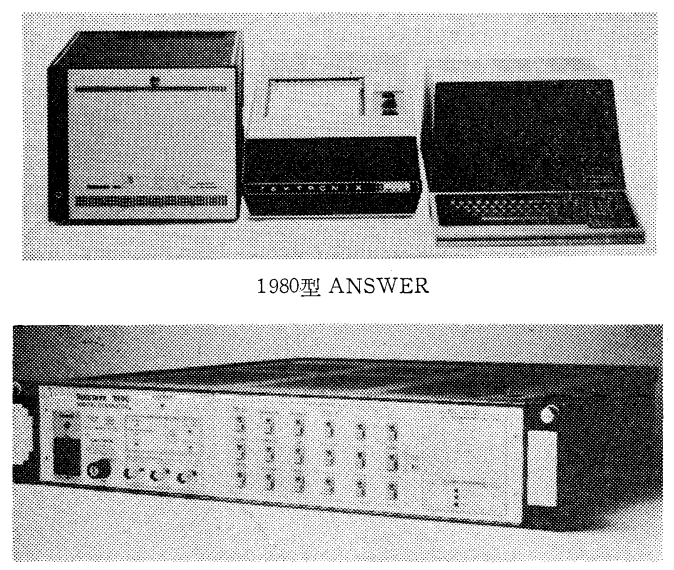

1900型ディジタルゼネレーター

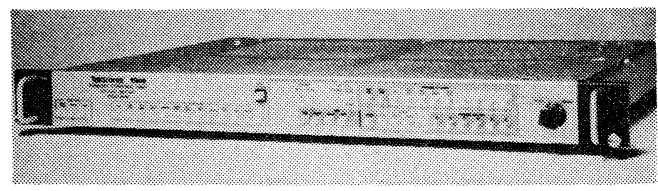

1900型ディジタルゼネレーター用リモコンユニット

9900 形マイクロプロセッサーをベースにしたデータプ ロセシング部とに分かれる，言語は特にビデオ信号を処 理するという特殊条件を満すために，ビデオ専用の拡張 BASIC を開発, 使用している. オペレーションシステ ムは ROM 44k ワードを使用し, ユーザーメモリーとし て $32 \mathrm{k}$ の RAM がある (1ワード 16 ビット). この他 にバッテリーバックアップの $8 \mathrm{k}$ の不揮発性メモリーが ある. この不揮発性メモリーには通常キーボードから入 力されるパラメーターリミット，つまり測定の上限，下 限のリミット設定值をストアしたり，プログラムの変更 情報, 資料データ, 測定結果などをストアするのに用い る.

この ANSWER では数個のクロックが用いられてい るが, リアルタイムクロック $(4 \mathrm{MHz})$ は時刻, 日付を データに表示したり，一定の時刻に自動測定を行うスケ ジュール運転に使われる. 必要に応じ外部 $1 \mathrm{MHz}$ クロ ックを用い，時間情報をステーションマスタークロック にロックすることもできる.ユーザーは RS-232 CCITT V. 24 入出力ポートにより, 各種ターミナル, プリンタ 一，モデムなよ゙と接続し，ANSWERシステムと対話す ることができる。すちろん，電話回線を利用してのリモ ートコール機能も持っている.

\section{2 高精度高速データアクイジション部}

この部分は測定しようとする信号を高精度に，かつ高 速にディジタル変換しデータとしてストアする部分で, これを基にプロセシング部でのパラメーター演算が行わ れる.

$118(36)$

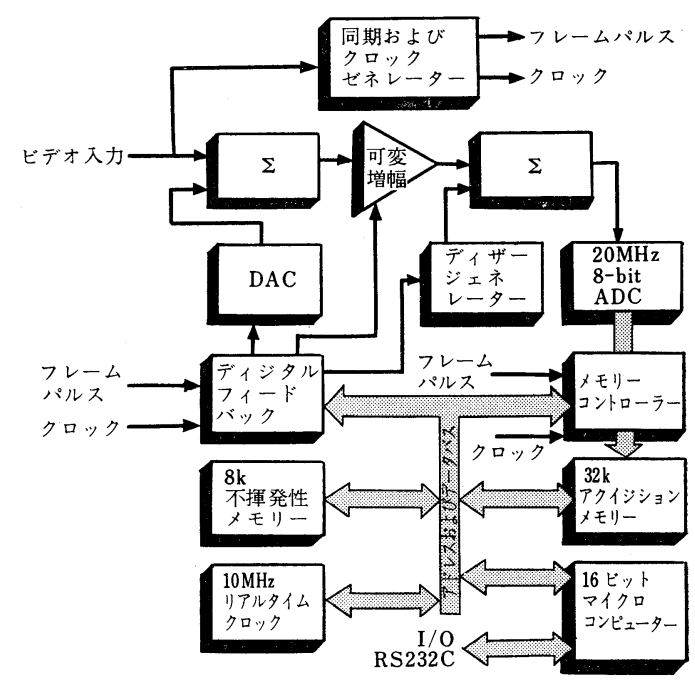

図 2 “ANSWER” の簡略系統図 (最大の分解能之精 度を確保するため多くの信号処理が行われる)

図 2 にデータアクイジション部の系統図を示す，ての 部分は, データを $\mathrm{A} / \mathrm{D}$ 変換する前の処理を行う前置増 幅部之, CPU からのデータによりこの前置増幅部を制 御するディジタルフィードバック部, それに A/D 変換 部之，そのディジタルデータをストアするメモリー部, およびこのメモリーを制御するメモリーコントローラー 部の 5 部門に大別できる.

前置増幅部は入力信号を単に増幅することのみなら ず, 後述の分解能， $S / N$ 等の改善を目的とした, 増幅 度, オフセット值のコンピューターによるダイナミック 制御を行う. A/D 変換部は $8 \mathrm{bit}, 4 f_{s c}$ で行われるが, $\mathrm{A} / \mathrm{D}$ 変換素子の直線性 (cut-point linearity) は実質 10 bit 以上であり, ディザーによる分解能改善を可能 にしている. A/D 出力は ECL 32k バイトの “VIDEO MEMORY” でストアされるが，連続しているテレビ信 号のどの部分を取込むかを，プログラムに従ってメモリ ーコントローラーがこれを制御する.

すなわち，プログラムの変更によりテレビ信号の任意 のラインの任意の部分（たとえば $2 T$ 信号のみとか， マ ルチバーストの $3.58 \mathrm{MHz}$ パケットのみなど）を多ライ ンにわたりストアできる．後にこれを処理するコンピュ ーター部により各パラメーターの測定が行われる.

\section{3. 高速度 $\mathbf{A} / \mathbf{D}$ コンバーター}

このシステムを完成するうえで最む重要なポイントが A/D コンバーターである. 市販の A/D コンバーターを すべてテストしたが高周波時のビット精度, 直線性の点 で満足する結果が得られず，乙れらの点を満足する 8 ビ ット $20 \mathrm{MHz}$ A/D コンバーターの自社開発を行った. 


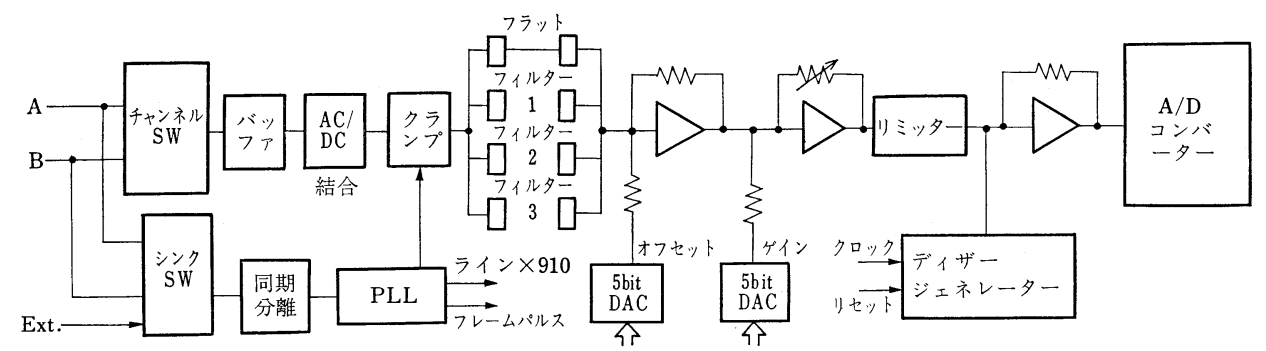

図 3 前置増幅部系統図 (入力チャンネル, 同時信号切替, AC/DC カップリング切普はプログラムにより行われる. ダイナミックオフセット, ダイナミックゲインコントロールはコンピューターからディジタルフィードバック回 路を通し，リアルタイムで制御される)

この $\mathrm{A} / \mathrm{D}$ コンバーターでは PAL の $4 f_{s c}$ クロック で RMS ェラーは \pm 0.125 LSB 以下, ピークェラーは \pm 0.25 LSB 以下となっており, 非常に良い精度を得て いる.

\section{4. 分解能の改善}

ビデオ信号のように，最初からある帯域以上のエネル ギーを持たない電気信号では，それを量子化した場合， ナイキストの定理による波形再現が非常に有効であり, またコンピューターによる演算はその理論を充分活用し 得るむのといえる，また，テレビ信号は，特にテストを 必要とするような信号は，かなりのノイズを含む可能性 があり，てのノイズによるサンプル誤差が測定データの エラーになるととを極力防がなければならない.またジ ッター等によるサンプルエラーむ同様である.

これは，テレビ信号のあるポイントをサンプルした時 の，そのデータの信頼性が重要であるというととであ り, むし， 4 倍の $f_{s c}$ でサンプルした場合の各ポイント データの信頼性が高ければ理論的にはいかなる点のデー 夕あ演算できるということである. ANSWER システム では 32 回の平均とディザー, ダイナミックオフセット, ダイナミックゲインコントロールの 3 つの手法により 4 $f_{s c}$ でサンプルするポイントデータの精度を非常に高く している.

\section{2 ダイナミックオフセットコントロール}

図3亿前置増幅部の系統図を示す. ダイナミックオフ セットはマイクロコンピューターからの精密オフセット 波形と入力ビデオ信号を加算することにより行われる. このオフセットパターンは, マイクロコンピューターか らの 5 ビットディジタルパターンとして出力され, ディ ジタルフィードバックメモリーにストアされる. ビデオ 入力信号に同期し, その内容を読出し, 精密 D/A コン バーター（精度 $0.01 \%$ ）に印加し，その出力が精密オフ セット信号として入力ビデオ信号に加算される．乙れに より測定したい信号部分の DC レベルを $\mathrm{A} / \mathrm{D}$ コンバー
ターのダイナミックレンジの中央に合わせることができ る.

\section{3 ダイナミックゲインコントロール}

ダイナミックオフセットの加算アンプ出力は, ディジ タルプログラマブルの可変利得アンプに加えられる. と の增幅段はダイナミックオフセットと同様, マイクロコ ンピューターからのゲインパターンにより, その回路利 得を, 波形取込時, リアルタイムで制御する.

図4にリニアリティーテスト信号にダイナミックオフ セットと, ダイナミックゲイン制御を加えた場合の効果 を示す. 入力信号は測定に必要なクロミナンス成分が 3 倍に増幅され実効的に 1 ビット以上の分解能向上に役立 っている.

\section{4 ディザー法}

A/D コンバーターに加えられる最後段で分解能搪大 の最む有効な手段であるディザーが行われている．乙の ディザーの手法は図 5 に示すようなカウンターと D/A コンバーターの組み合せにより発生するディザージェネ

(a)

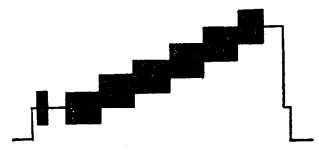

(b)

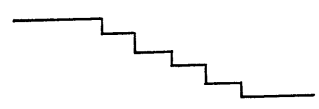

(c)

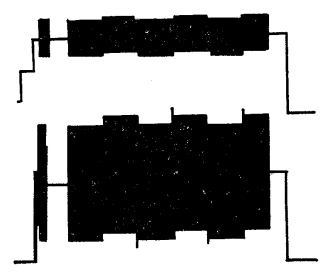

図 4 リニアリティーテスト信号にダイナミックオフ セットとバリアブルゲインを加えると，测定の 分解能と精度を大幅化高められる 


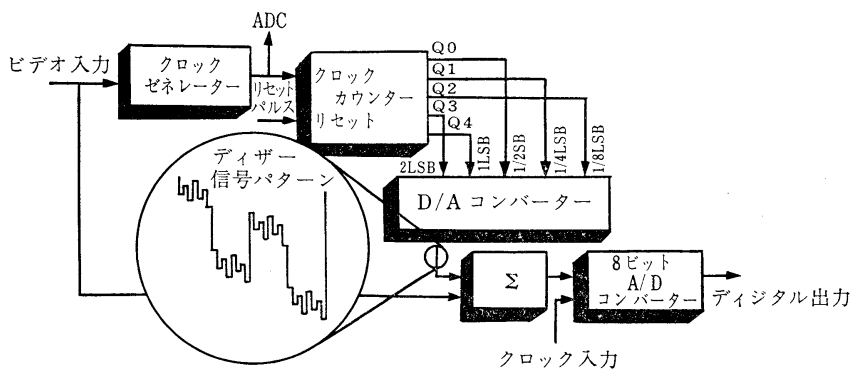

図 5 ディジタルディザーゼネレーターにより，32段の精密オフセッ トレベルが作られ，ビデオ入力信号に加えてディジタイズする ととにより実質的な分解能と精度を高める

レーター出力のパターンを順次繰返される入力信号にで くわずかの DC 成分として加えるととで行われ，量子化 プロセスの精度と分解能を改善するてとに成功してい る. 図 5 にディザーシステムの系統図を示す.

カウンター出力は $\mathrm{D} / \mathrm{A}$ コンバーターのデータ入力に 加えられ，との D/A コンバーターの出力アナログパタ ーンが最初の入力ビデオ信号に加算される．との加算さ れた信号がディジタイザーに加えられる。

ビデオ入力信号が 32 回繰返されると(走査線 32 本分) カウンターがリセットされ，同様のプロセスを繰返す．

てのアナログディザーパターンは A/D コンバーターの 1 LSB 以下の精密オフセット DC 信号として 32 ライン にわたり加えられる．図6にその論理を示す，実際には 8 ラインにわたり 8 分の 1 LSB までの DC 成分をオフ セットをすれば理論的に 3 ビットの分解能改善が行われ るが，さらに士 1 ビットおよび士2ビットのスケールの スライディングを行い, 直線性エラー（カットポイント リニアリティー誤差）による精度落ちを補償している.

てのディザーの手法はすでに周知と思うが，どのよう

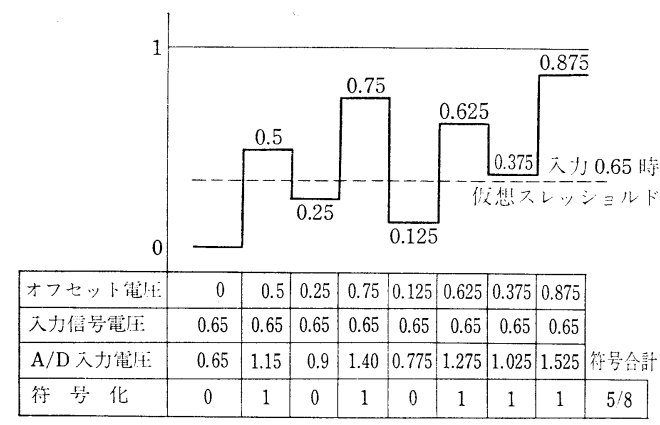

図 6 ディザー解説図（図 5 のように 5 bit カウンター と D/A コンバーターを接続した場合の下 $3 \mathrm{bit}$ 出力図. 入力信号を 0.65 之仮定した場合の符号 化出力で 8 回のオフセットで $5 / 8=0.625$ が得ら れ, 理論的には 3 bit 改善される.上 2 bit はり ニアリティー補償のためのスライディングスケ ールとして使われる)
いる.

な $\mathrm{A} / \mathrm{D}$ コンバーターにも適用できるとい うことではなく，理論分解能とほぼ同等の カットポイントリニアリティーを持った A/D コンバーターでないと意味のないむ のになってしまう，そして，ビデオ信号の ように当然ノイズ成分からのエラーを防ぐ 意味でむ必要になる信号の平均化を行う場 合, このディザーの手法は少ないデー夕処 理で最大の分解の改善効果が得られる。 ま た，このシステムではほとんどの測定は 32 ラインの平均で行われ，ランダムノイズに よるマスキングをみかけ上 $15 \mathrm{~dB}$ 軽隇して

\section{ANSWER システムの測定方法}

コンピューターを用いる測定で何が測定できるかを論 ずると，その可能性は無限というほど広がる.ナイキス 卜定理による原信号の再生のための $\sin x / x$ 補間, , イズ測定のフィルタリングのためにも利用されている FFT, IFT 信号処理, それに DG, DP 測定も ANSWER BASIC に盛込まれている. ここでは，よく行われる代 表的な测定項目について簡単に説明する.

\subsection{DG, DP 測定}

非直線ひずみを測定するに必要なアルゴリズムを考え ると $4 \times f_{s c}$ でディジタイズする利点が明らかになる。 基準サブキャリアの $0^{\circ}, 90^{\circ}, 180^{\circ}, 270^{\circ}$ でサンプルさ れた 4 つのディジタルワード $W_{1} \sim W_{4}$ を考えてみる.

図8にそれを図示する.

定常状態では次式が成立つ

$$
\begin{aligned}
& W_{1}=Y+Q \\
& W_{3}=Y-Q \\
& W_{2}=Y+I \\
& W_{4}=Y-I \\
& \text { ( } I \text { はインフェーズ成分, } Q \text { は直交成分) }
\end{aligned}
$$

したがって

$$
\frac{W_{1}+W_{2}+W_{3}+W_{4}}{4}=Y
$$

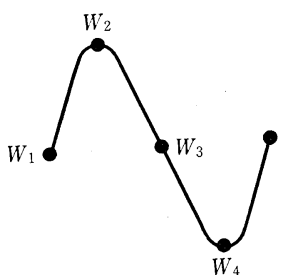

図 7 サブキャリアのサンプリングで 4 点のディジタ ルデータが作られる. サンプル 2 はサブキャリ ア $(I)$ と同相, サンプル 1 は直交成分 $(Q)$ と同 相でサンプルされる 


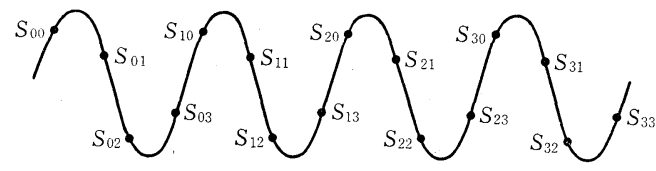

図 8 DG, DP 平均化プロセス図 指定のサイクル数の振幅, 位相を平均化し, さらに 32 ラインの平均をとる

$A=\frac{1}{K+1} \sum_{i=0}^{K} \sqrt{\left(S_{i_{0}}-S_{i_{2}}\right)^{2}+\left(S_{i_{1}}-S_{i_{3}}\right)^{2}}$

$O P V=\frac{1}{N L} \sum_{J=0}^{j=N L-1} A_{j}$

$\varphi=\frac{1}{K+1} \sum_{i=0}^{K} \arctan \frac{S_{i_{0}}-S_{i_{2}}}{S_{i_{1}}-S_{i_{3}}}$

$A=$ 振幅, $O P V=$ 振幅值出力, $\varphi=$ 位相,

$N L=$ 平均化ライン数

$$
\begin{aligned}
& \frac{W_{1}-W_{3}}{2}=Q \\
& \frac{W_{2}-W_{4}}{2}=I
\end{aligned}
$$

ディファレンシャルゲインを計算するには, 変調ステ アケース信号の各ステップの $\left(I^{2}+Q^{2}\right)^{1 / 2}$ を評価すると とで行える．実際にはデータの信頼性向上のため図 8 の ようにプログラムにより指定されたサイクルだけ上記演 算を繰り返し，平均化されたデータを 1 パケットの測定 結果とする，乙の結果はさらに 32 ラインにわたり平均 される.

$$
\begin{gathered}
\text { ディファレンシャルフェイズも同様, } \\
\phi=\operatorname{Arctan} I / Q \\
\phi=\operatorname{Arctan} \frac{W_{2}-W_{4}}{W_{1}-W_{3}}
\end{gathered}
$$

で算出される，乙れを各ステップについて実行し，各ス テップの位相差を計算し, ディファレンシャルフェイズ とする. これらのデータは, 前途の 32 ライン平均む行 われているため，ノイズによる誤差，または一時的な非 直線ひずみの影響を取除くことができる．またての応用 で，カラーバー等の位相を正確に测定できる.

\section{2 クロミナンス・ルミナンス遅延量の測定}

クロミナンス・ルミナンス遅延の測定には, 変調 12.5 $T$ パルスまたは変調 $20 T$ パルスが用いられる．乙の信 号を用いての測定には良く知られたベースラインひずみ から測定する方法があるが，サグ等のひずみを複合的に 持っている場合や，その遅延量が特に大きい場合など は，乙のベースラインを直接測定する方法は結果的にエ ラーを生じやすい，乙の ANSWER システムでは新し い別の手段をとっている.

まずストアされた変調 $\sin ^{2}$ 波のルミナンス成分とク ロミナンス成分をディジタルフィルターで分離する（図 9 参照). 次にクロミナンス成分のエンベロープを演算

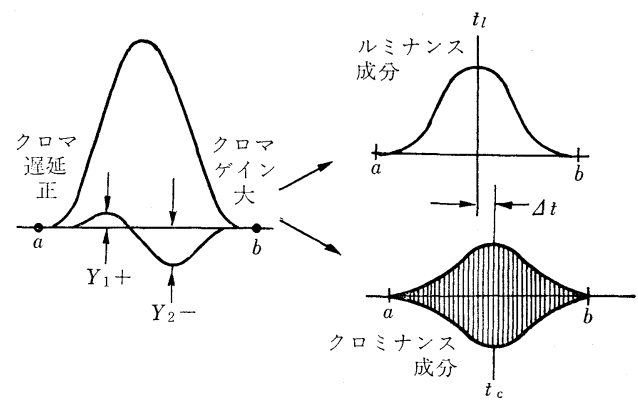

図 9 クロミナンス・ルミナンス遲延測定（ルミナン スタイミング $t_{l}$ とクロミナンスタイミング $t$ との差時間 $\Delta t$ が幄延量となる)

し（クロミナンスエンベロープは1つの命令の実行で得 られる)，さらに区間指定の 2 点間 $a, b$ が水平になる ようにデータから傾斜值を減算する (サグを除くため), ルミナンス波形とクロミナンス波形の重みづけされた中 点（区間積分值の 2 分の 1 になる水平ポイント）を算出 する、乙れらの演算はすべてテレビ信号測定のために用 意された拡張 BASICの1つの命令を実行することで行 える. この 2 つ中点データの時間差がクロミナンスと ルミナンスの遅延量となる.

ての方法は，変調 $\sin ^{2}$ 波をコンピューターを使用し 測定する場合，底辺ひずみを測定したり，単にクロミナ ンス・ルミナンスのピーク值を算出するのに比べ, 非常 に良い結果が得られる.

\section{3 時間測定と時間分解能}

図 10 の表にタイミングパラメーター測定例を示す. これらのパラメーターは，FCC または電波法などの基

$B, E, E$ SHOW 1981

(REPORT)

\section{RS170A H. TIMING}

LIMIT FILE: FACTOR.LIM

$A P L=40 \%($ IRE $)$
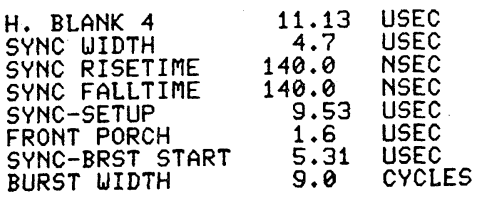

$B, E, E$ SHOW 1981

RS170A U. TIMING

LIMIT FILE: FACTOR.LIM

$A P L=53 \times($ IRE $)$

\section{U. BLANK $20 F 1$ \\ U. BLANK $4 \mathrm{FZ}$ EQUALIZER WIDTH

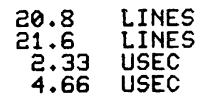

図 10 タイミングパラメーターの自動測定例 
準に従った半振幅点でのタイミングを数 ns の精度で読 取ることができる．乙れらの時間測定分解能は，4 倍の サブキャリアサンプルから， $\pm 70 \mathrm{~ns}$ ということを考えが ちだが $\sin x / x$ ディジタルインタポレーションにより数 ns まで拡張されている. $\mathrm{SCH}$ タイミング測定を例にと ると $3.58 \mathrm{MHz}$ の 19 サイクルは $5,307 \mu \mathrm{s}$ であるが, この測定精度は $\pm 0.6 \%$ すなわち $\pm 35 \mathrm{~ns}$ でなければな らない，最良の波形モニターでもこれだけの精度は得ら れない. この ANSWER システムでは最初にバースト 振幅の $1 / 2$ を越す直前のゼロクロッシング点を算出した 後, $4 \times 19=76$ サンプルだけ早い点のメモリーを調べ， 瞬間に Sync を評価する. 振幅がシンク振幅の $1 / 2$ 亿等 しければ，SCH タイミングであるといえる。また，ゼ ロクロッシング直前にとられたバーストサンプルが正か 負かでカラーフレミングを決定することすできる.

\section{6. ディジタルゼネレーター 1900 型}

\section{1 精度の向上}

テレビ信号の測定はほとんどオープンループ測定とい える. 単に回線テストのみならずビデオ機器の測定をテ スト信号を使って行おうとする場合，その測定精度が上 がるほど, 信号源に要求される精度は大きくなる.

信号精度向上にタイミング精度と振幅精度がある.ア ナログ式の信号ゼネレーターはルミナンス成分とクロミ ナンス成分を別々に作り後に合体する方法が一般的であ る. ディジタルゼネレーターでは ROMデータの読出し からクロミナンス成分とルミナンス成分はすべて同一の 経路を通り出力される. 最終段におけるフィルター位相 特性のみを管理すれば, アナログ式のようなクロミナン スノルミナンス遅延調整の必要は全くない。 またその䛊 差む皆無に等しい.

たとえばマルチバーストパケット周波数精度は通常ア
ナログ式では 2 3\% ほどであるが, 1900 型ディジタル ゼネレーターでは $4 f_{s c}$ サンプリングクロックで規定さ れる精度となり，拈打む补 $0.0003 \%$ 以内であろう。乙 のようなマルチバーストパケット時間関係が一定である ということのみならず，同期信号とバースト位相を規定 した SCH タイミング (EIA RS-170A による) む非常 に安定に供給されることは㧍わ加りの通りである. SCH 位相を変える唯一の方法は ROM データを変更するしか

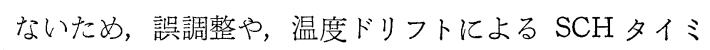
ングェラーは発生しない.

振幅精度については, すべての振幅情報が 2 進コーデ イングであるため, 数種の信号相互間の誤差は皆無に等 しいであろう. 絶対精度については唯一DA コンバータ 一の精度によるが, 10 ビット DA コンバーターのスケ ールファクターは 5. 6 LSB/IRE となり, DA コンバー ター精度を $\pm 0.5 \mathrm{LSB}$ と仮定すると, 最悪值の誤差は 0.2 IRE 以下となる. その他クロミナンス・ルミナンス 利得むすべて数学的に処理された正確なピーク值を持っ ており, DG 測定等の精度を向上させている.

1900 型の簡単な系統図を図 11 亿示す.

\section{2 新しいテレビジョンテスト信号}

(1) マルチパルス信号

図12にマルチパルス波形を示す．マルチパルス信号 は以前ヨーロッパで使われていたてとがあるが，米国， 日本などでは比較的新しいむのである. ての信号はクロ ミナンス・ルミナンス遅延測定に用いられている変調 12.5Tパルスをさらに発展させたもので，マルチバース 卜信号との結合形といえる.

$\sin ^{2}$ 変調 $12.5 T$ パルスあるいは $20 T$ パルスの目的 は，その名称からクロミナンス遅延から起こる“色ずれ” のように思われがちだが，実際に発生する $3.58 \mathrm{MHz}$ 点 での数十ns の遅延は, 画像評価に“色ずれ”として影響

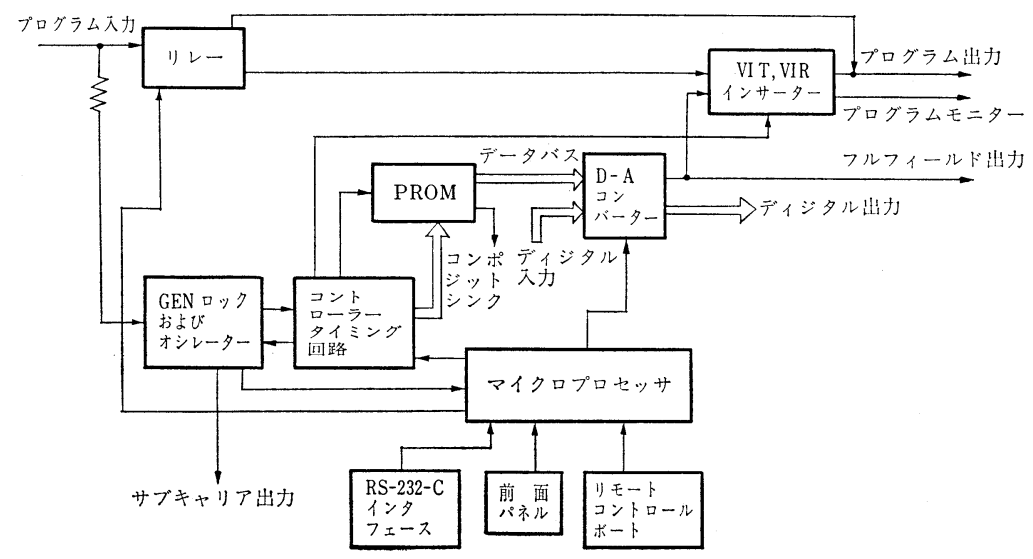

図 11 全ディジタル信号発生システム (10ビットD/A コンバーター, PROM はマイクロプロセッサーにより制御される) 


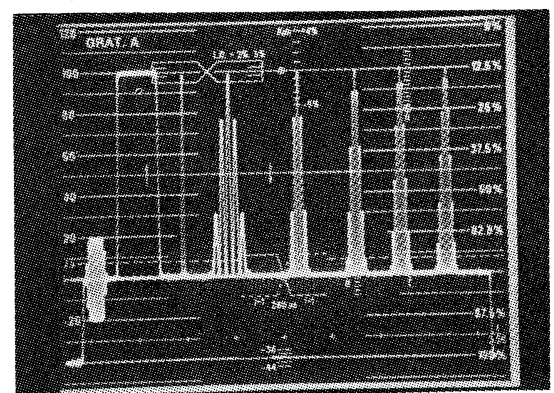

図 12 マルチパス

(左からバー，2T，1，2，358，4.2 MHz)

を及ぼすほどのものではなく, 周波数/位相特性の悪さ から起とるパルスレスポンスの不良による画像劣化とし ての評価パルスと考えるべきであると思う（ただし，家 庭用 VTR のようにクロミナンス分離を行い処理後, 再 度合成する場合などは，正にクロミナンス/ルミナンス 遅延特性の測定といえる).

ビデオ帯域では周波数応答特性の代表的なむのとして マルチバースト信号があるが，てのマルチバースト信号 では，各パケット周波数の振幅応答特性を測定している が，位相特性を評価できない．乙れを可能にしたあのが マルチパルス信号である. 周波数は $1,2 ， 3 ， 3.58,4.2$ $\mathrm{MHz}$ で $1 \mathrm{MHz}$ の $\mathrm{HAD}$ は $25 \mathrm{~T}$ ，他は $12.5 T$ である。

\section{(2) $\sin x / x$ 信号}

図13に $\sin x / x$ パルス信号およびその反転信号を示 す.これらのパルス特性はスペクトラムアナライザーを 用いての周波数領域での測定でその有効性を発揮する.

ANSWER システムでの自動測定では FFT 機能を利用 できる. $15 \mathrm{kHz}$ のライン周波数から $4.5 \mathrm{MHz}$ までの周 波数領域でフラットなスペクトルを生ずる（図 14）。 ア ナログ回路でての特性を得るためには理論的に無限に結 合した素子のフィルターが必要になり，乙の信号の発生 は不可能であろう. ディジタル信号発生器の最む特徵之 すべき点でああろう．との信号についての考察は多々あ るが今回の自動測定のテーマから外れるし，紙面の都合 からも詳細は次の機会にゆずりたい．

ての 1900 型ディジタルゼネレーターは，以上の信号 に代表されるようなディジタルならではの数多い特徽が あるが，自動測定に供するためにコンピューターからの リモート切替機能む備えている. またVITS はてのリ モート機能により任意のフィールドの任意のラインに Key-in できるようになっている.

\section{7. 応 用 測 定}

\section{1 自動モニタリング}

1900 型ディジタルゼネレーターについて，てれを充

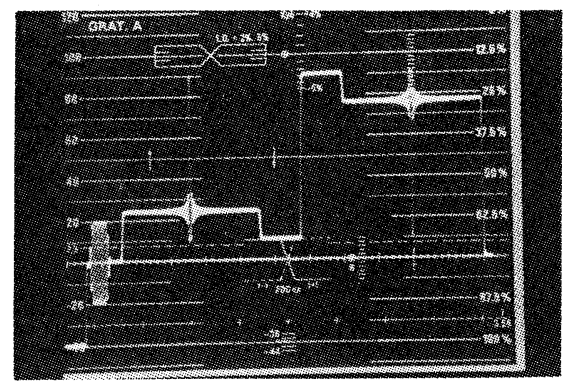

図 $13 \sin x / x$ 波形

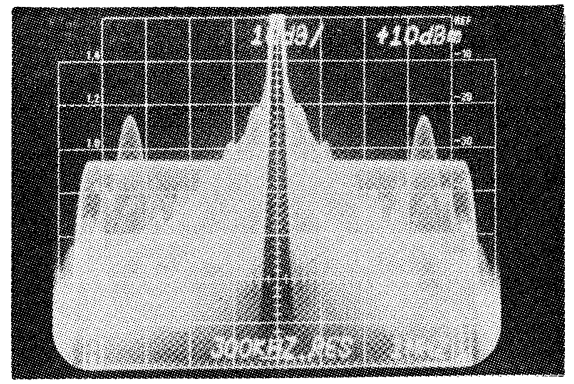

図 $14 \sin x / x$ 信号のスペクトル

(REPORT)

NTC-? COMPOSITE UITS F1 L1?

LIMIT FILE: FACTOR.LIM

$A P L=7 \%($ IRE )

\begin{tabular}{|c|c|}
\hline $\begin{array}{l}\text { BAR AMPL } \\
\text { SYNC AMPL } \\
\text { BURST AMPL } \\
\text { CHR-LUM GAIN } \\
\text { REL BRST GN } \\
\text { REL BRST PH } \\
\text { DIFF GAIN } \\
\text { DIFF PHASE } \\
\text { LUM NL DST } \\
\text { CHR-LUM DELAY } \\
\text { LINE TIME DST } \\
\text { PULSE BAR } \\
\text { ET PULSE RING } \\
\text { T STEP RING LD } \\
\text { T STEP RING TR TR }\end{array}$ & $\begin{array}{r}97.8 \\
-40.4 \\
38.1 \\
-3.4 \\
-1.3 \\
-21.8 \\
1.2 \\
.8 \\
5.5 \\
5.0 \\
98.4\end{array}$ \\
\hline
\end{tabular}

图 15 NTC-7 コンポジットVITS 自動測定例

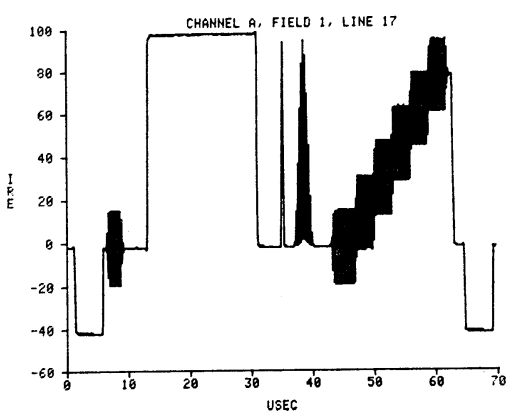

図 16 NTSC-7 コンポジットVITS A/D 波 形（任意の部分を拡大表示できる） 


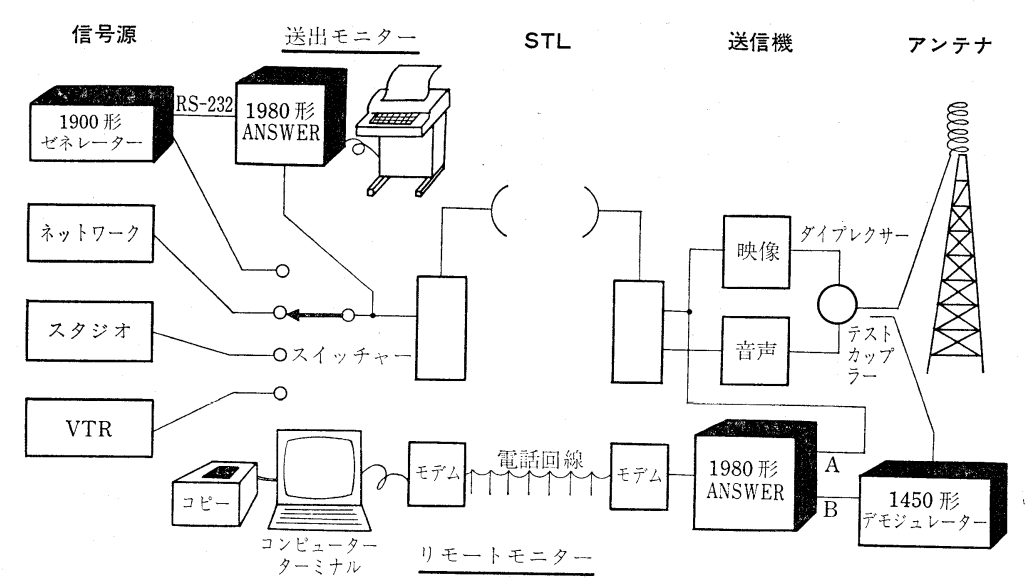

図 17 自動モニタリング例（放送局における自動モニタリング例. 送出モニターは必要 なデータを定期的にプリントアウトする.リモートモニターにより無人運転の送 信機を常に監視できる．定期データむ自動的に得られる)

分知るためには，さらに説明を加えるべきと思うが，今 回のテーマ, 自動測定と ANSWER システムについて その利用例を記し，ての稿を終らせていただきたい.

このシステムの第一の目的は信号が定められた規準 (電波法等) 飞適合しているかどうかを，測定時間を含 めてプログラムし，自動監視することである.

図 15 亿示す NTC-7 コンポジットVITS 測定例之, 前述の図 11 の タイミング測定例を参照願いたい. 許 容值を越えた場合は警告を出すととができ，てのための リミット設定は任意に行える. またとのVITSをグラフ 化するてとあでき, グラフィックソフトウェアによりデ 一タを集約し, エラー分布図等のデータ処理グラフむ作 成できる. 図16にVITS 波形を示す.

また，てれらの測定はリモートコール機能による電話 回線を用いた自動レポートあ行える.乙れはシステムに あらかじめ電話番号を記憶させておき，プログラムによ り設定された時間に送出サイトに電話をし、レポートす るシステムであるが, 専用回線を使用しないと日本の場 合はむずかしい点む多いようである。 また回線が自由に 使用できるのであれば，乙ちらから特定の“自動測定 ANSWER システム”を呼び出し，パスワードを送れば 全国の各点のVITS データがどてからでむ拾えるとい うことが可能になる．図17 亿自動監視例を示す.

\subsection{VTR 等の機器自動測定}

回線ひずみの自動測定が行えるというととは VTR, 増幅装置等をブラックボックスと見なし，ひずみを持っ た伝送回線と考えれば測定が行えるというととになる。

しかしながらVTRのように通常の伝送路では考えられ ない特殊ひずみ，たとえば時間軸ひずみ，クロミナンス 分離した場合の特殊ひずみ, モワレ等, 特に配慮が必要
な測定む多い。

たとえば，よく計測するDPについて考えれば, VTR の時間軸ひずみはすべて位相ひずみとなり, 通常の DP 測定ではこの位相ひずみが DP 測定值に加わることはい うまでもない.しかしベクトルスコープ上にも同様の表 示が現れるわけで，画像評価の考え方からすれば，乙れ を評価するととで良しとするととむひとつの考え方であ ろう、しかしながらメーカー等で真の信号評価を考える べきところでは，乙の二者は，はっきり分離する必要が ある。

ての ANSWER システムでは A/D 変換汇リアルタ イムで処理できる高速コンバーターを使用しており, 時 間軸ひずみを含む信号むりアルタイムで任意のラインを メモリーに転送できる，補間む前述のようにコンピュー ターによる関数補間を行っており, その1ラインを評価 することに何の支障むない。また複数を評価し平均む行 える. しかし通常の回線ひずみ測定のプログラムで DP を測定すれば，時間軸ひずみによる位相誤差を DP とし て評洒するであろう. ANSWERでは時間軸エラーを読 む機能をファームウェアレベルで持っており, 時間軸エ ラーにより発生する位相誤差分を演算し, DP 湘定值か ら差し引けげ純粋な DP 值が計算できる.

近年, VTR 産業が盛んで自動測定システムを採り入 れる場合が多いようだが，AFCによるサンプルクロッ クの制御を大きく行った場合, TBC を測定器側に採用 した場合等, それらが測定結果に，何を測ったかという 意味上で大きな影響を及ぼすととを忘れてはならないと 思う.

ANSWERシステムは現在スペクトラムアナライザー で行われている“モワレ”測定む FFTにより理論解析 
は可能である(完成ソフトウェアはないためユーザーが ANSWER BASIC でプログラムを書く必要がある). 今後ソフトウェアの開発でこれらの測定に新しい考え方 が採用されていくかも知れない.

\section{8.むす び}

SMPTE でコンポーネントレベルディジタルテレビジ ヨン規格のY信号サンプル周波数を $13.5 \mathrm{MHz}$ にすると いうととから，ディジタル機器の様相む変わろうとして いる. ディジタル入・出力を持つ機器では特に問題にな る.また現在のコンポジットレベルディジタルでは，デ イジタル信号でのインタフェースはほとんど行われてい ないが, コンポーネントレベルではこれを目指してい る. 信号計測も現在行われているアナログ伝送路の測 定から，一挙にディジタル伝送特有の計測に変わる.
SMPTE では現アナログからディジタルへの移行に関す る委員会を持った．テレビジョン計測む革新の時代が来 るととは遠いことではないだろうと思う。

(昭和 56 年 11 月 5 日受付)

\section{〔参 考 文 献〕}

1) Tektronix, Inc: Tektronix Original Text, Tektronix (1980)

2) Charles, W. Rhodes: Automated and Digital Measurement of Baseband Transmission Parameters, SMPTE J., 86 (1977) 832

3）町永欣一：“ANSWER” テレビ信号自動測定システム，放 送技術, 1 (1981)

4) Charles, W. Rhodes: The Application of Digital Techniques for Video Measurements, Tektrorix, Inc. Original

5) Tektronix: Tekscope, Tektronix, 12, 2 (1980)

\section{テレビジョン学会誌 3 月号「ビデオディスク」小特集予定目次}

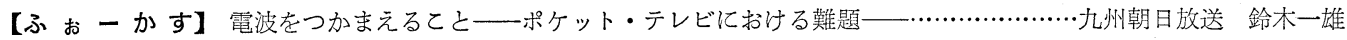

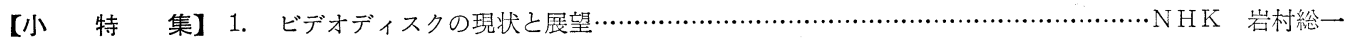

2. ビデオディスクの精密微細加工技術

2-1. VHD/AHD ビデオディスク ………………...........................本ビクター 金城寿雄

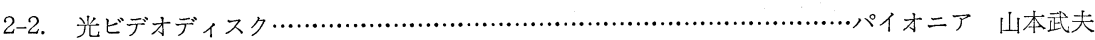

2-3. CED システム ……………………................................... R C A 技研 奥野芳啓

3. ディジタルオーディオディスク ……………..........................................菱電機 石田禎宣

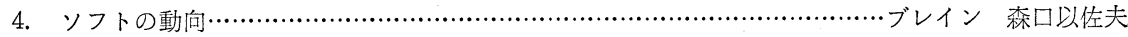

【技 術 解 説】テレビジョンシステム評価用チャート

——テレビジョン学会テストチャート集の刊行に寄せて——........... N H K 和久井孝太郎・日下秀夫

【論 文・資 料】近接形光電面技術の開発とイメージインテンシファイアへの応用

$\cdot \mathrm{NHK}$ 河村達郎・東芝 柳澤卓司

予測誤差信号のマルコフ性を利用した画像用 DPCM 符号化方式

理科大 伊東 晋・関根慶太郎・東大 宇都宮敏男 厚い半無限導体板による平面 $\mathrm{H}$ 波の散乱…………………….九大 青木和男・中村繁樹・内田一徳

【講座】放送現業技術（第2 回）：1. 映像技術 (II) 一一番組制作の設備——……………... $\mathrm{N} \mathrm{HK}$ 清水 裕

【現 場 だより】大阪大学産業科学研究所……………………………………..........................阪大 角所 収

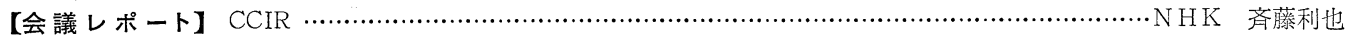

International Symposium Graphics and Text Communication ……………......電 菊本義文

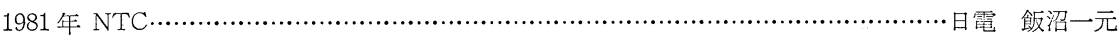

